\title{
Synthesis, Crystal Structures, and Antimicrobial and Antitumor Studies of Two Zinc(II) Complexes with Pyridine Thiazole Derivatives
}

\author{
Zou Xun-Zhong, ${ }^{1}$ Feng An-Sheng, ${ }^{1,2}$ Zeng Fu-Ran, ${ }^{1}$ Lai Min-Cheng, ${ }^{1}$ Liao Yan-Zhi, \\ Mei Meng $\left({ }^{3},{ }^{3}\right.$ and Li Yu $\left(\mathbb{1}^{1}\right.$ \\ ${ }^{1}$ Guangdong Research Center for Special Functional Building Materials and Its Green Preparation Technology, \\ Foshan Research Center for Special Functional Building Materials and Its Green Preparation Technology, \\ Guangdong Industry Polytechnic, Guangzhou 510006, China \\ ${ }^{2}$ College of Light Industry and Food, Zhongkai University of Agriculture and Engineering, Guangzhou 510006, China \\ ${ }^{3}$ Wuhan Children's Hospital, Tongji Medical College, Huazhong University of Science and Technology, Wuhan 430015, China \\ Correspondence should be addressed to Mei Meng; meimeng1992@126.com and Li Yu; liyuletter@163.com
}

Received 25 June 2020; Accepted 4 September 2020; Published 15 September 2020

Academic Editor: Patrick Bednarski

Copyright ( $) 2020$ Zou Xun-Zhong et al. This is an open access article distributed under the Creative Commons Attribution License, which permits unrestricted use, distribution, and reproduction in any medium, provided the original work is properly cited.

Two pyridine thiazole derivatives, namely, 4-(pyridin-2-yl)-2-(2-(pyridin-2-ylmethylene)hydrazinyl)thiazole (L1) and 4-(pyridin3-yl)-2-(2-(pyridin-4-ylmethylene)hydrazinyl)thiazole (L2), were afforded by a cyclization reaction between $\alpha$-haloketone and thioamide, and their $\mathrm{Zn}$ (II) complexes were prepared by the reaction of ligands and corresponding metal salts, respectively, and characterized by X-ray diffraction and elemental analysis. Both crystals were obtained by ether diffusion and crystallized in a monoclinic system. The in vitro antimicrobial activity of the $\mathrm{Zn}$ (II) complexes and ligands was screened using the microplate reader method, and in vitro antitumor activities of the complexes were evaluated by MTT, with a view to developing new improved bioactive materials with novel properties. The biological activity studies of the compounds showed that the metal complexes were more active than the free ligands, and some compounds had absolute specificity for certain bacteria or cancer cell lines.

\section{Introduction}

Thiazole ring and pyridine ring are structural units with extensive biological activities, such as antibacterial [1], antitumor [2], antiviral [3], anti-inflammatory [4], and hypoglycemic [5] activities. Hydrazone compounds have also attracted much attention in various fields, especially in pesticide and pharmaceutical fields due to their unique physiological activity and strong coordination ability $[6,7]$. Therefore, the introduction of pyridine hydrazone group into molecule containing thiazole is likely to produce stronger biological activity according to the synergistic effect of drug combination principles. Because of the particularity of the structures, thiazole ligands containing pyridine and hydrazone groups with multiple coordination sites often have good metal coordination ability which can form stable complexes with different transition metal $[8,9]$. Besides, the spatial conformation of the complex is determined by its coordinated modes, which have great influence on the biological properties of the compound [10-12]; the studies on transitional metal compounds of pyridine thiazole ligands have been of great significance. Co(III) complexes based on (1,3-selenazol-2-yl)- and (1,3-thiazol-2-yl)hydrazone were reported to have potent antimicrobial and antioxidant activity [13]. To further study the biological, physical, and chemical activities of these compounds and their $\mathrm{Zn}$ (II) complexes, two thiazole derivatives, L1 and L2, were synthesized by the cyclization reaction of pyridyl 
thiosemicarbazide and $\alpha$-bromopyridine (Scheme 1). Complexes $\left[\mathrm{Zn}(\mathbf{L} \mathbf{1})_{2}(\mathrm{TsO})_{2}\right](1)$ and $\left[\mathrm{Zn}(\mathrm{HL} 2) \mathrm{Br}_{3}\right] \cdot 2 \mathrm{DMF}$ (2) were obtained by coordinating the ligands with $\mathrm{Zn}(\mathrm{TsO})_{2}$ and $\mathrm{ZnBr}_{2}$, respectively. The ligand L2 and complexes were characterized by elemental analysis (EA) and single-crystal diffraction. The inhibitory activities of these compounds against seven pathogenic bacterial strains, namely, Escherichia coli (E. coli, ATCC 25922), Staphylococcus aureus (S. aureus, CMCC(B) 26003), Salmonella typhimurium (S. typhimurium, $\mathrm{CMCC(B)} \mathrm{50071),} \mathrm{Bacillus} \mathrm{subtilis}$ (B. subtilis, ATCC 6633), Shigella flexneri (Sh. flexneri, CMCC(B) 51572), Vibrio parahaemolyticus (V. parahaemolyticus, ATCC 17802), and Pseudomonas aeruginosa (P. aeruginosa, ATCC 9027), and four human cancer cell lines (human lung cancer cells A549, human breast cancer cells BT-20, human ovarian cells MCF-7, and human osteosarcoma cells U20S), were tested.

\section{Experimental Setup}

2.1. Materials and Methods. All the starting materials and reagents in this work were obtained commercially and used without further purification. Elemental analyses were performed on a vario EL analyzer (Elementar, Germany) and IR spectra on an Avatar 330 FT-IR spectrometer (Thermo Nicolet) with potassium bromide pellets. ${ }^{1} \mathrm{H}$ NMR spectra were determined by Bruker AVANCE-III 500 at $300-400 \mathrm{MHz}$, and MestReNova software was used for data analysis. Chemical shifts ( $\delta$ values) and coupling constants ( $J$ values) are reported as $\mathrm{ppm}$ and $\mathrm{Hz}$, respectively. The following abbreviations are used: $s$, singlet; $\mathrm{d}$, doublet; $\mathrm{t}$, triplet; q, quartet; m, multiplet; br, broad. Antimicrobial tests were performed on a SpectraMax ${ }^{\circledR}$ ABS Absorbance Reader (Molecular Devices). Single-crystal X-ray diffraction was carried out by a Bruker Smart Apex-CCD and Agilent SuperNova diffractometer. The UV-Vis spectra were recorded on an Agilent Cary 60 spectrophotometer.

2.2. Synthesis of Ligands L1 and L2. A mixture of 2-pyridine formaldehyde ( $10.7 \mathrm{~g}, 0.1 \mathrm{~mol}), 50 \mathrm{~mL}$ ethanol, $50 \mathrm{~mL} \mathrm{H}_{2} \mathrm{O}$, and $5 \mathrm{~mL} 36 \%$ concentrated hydrochloric acid was added to a $250 \mathrm{~mL}$ three-neck flask with magnetic agitator and reflex tube at $25^{\circ} \mathrm{C}$. Thiosemicarbazide $(10.9 \mathrm{~g}, 0.12 \mathrm{~mol})$ in $10 \mathrm{~mL}$ ethanol was added slowly, and the solution immediately became yellow solid. After being stirred for $0.5 \mathrm{~h}$ and refluxed for $2 \mathrm{~h}$, the solid was filtered and rinsed with ethanol to give the N-2-pyridine-methyl-thiosemicarbazide hydrochloride (20.2 g, yield $93.5 \%$, Compound $\mathbf{A}$ ) as a yellow acicular crystal [14].

2-Acetyl pyridine $(12.1 \mathrm{~g}, 0.1 \mathrm{~mol})$ was added to a solution of ice acetic acid $(85 \mathrm{~mL})$ and hydrobromic acid (40\%, $13 \mathrm{~mL}$ ), and the mixture was stirred for $10 \mathrm{~min}$ under ice bath. After being completely cooled, bromide $(0.1 \mathrm{~mol}$, $5.2 \mathrm{~mL}$ ) was added three times slowly. Then, the reaction mixture was stirred for $0.5 \mathrm{~h}$ at $0^{\circ} \mathrm{C}, 2 \mathrm{~h}$ at $40^{\circ} \mathrm{C}$, and $2 \mathrm{~h}$ at $75^{\circ} \mathrm{C}$, and the solution gradually changed from dark brown to light yellow with white crystal solid precipitation. After the reaction system was cooled to room temperature, $80 \mathrm{~mL}$ ethyl ether solution was added. Then the mixture was stirred continuously for $10 \mathrm{~min}$, filtered, and washed with dry ethyl ether three times to give bromo-2-acetylpyridine hydrobromide (19.5 g, yield 90.3\%, Compound B) as a white crystal [15].

N-Pyridin-2-ylmethylene-N'-(4-pyridin-2-yl-thiazol2-yl)-hydrazine (L1): N-2-pyridine methylene-thiosemicarbazide hydrochloride $(10.8 \mathrm{~g}, 0.05 \mathrm{~mol})$ and acetyl pyridine hydrobromide $(10.8 \mathrm{~g}, 0.05 \mathrm{~mol})$ were added to $160 \mathrm{~mL} \mathrm{50 \%} \mathrm{ethanol} \mathrm{solution} \mathrm{at} 25^{\circ} \mathrm{C}$. After being refluxed for $2 \mathrm{~h}$, the mixture was cooled to room temperature and adjusted to neutral with $10 \%$ sodium hydroxide solution. The resultant solid was filtered, washed repeatedly with distilled water, and recrystallized with methanol to give N-pyridin-2-ylmethylene- $\mathrm{N}^{\prime}$-(4-pyridin-2-yl-thiazol2 -yl)-hydrazine $(9.2 \mathrm{~g}$, yield $65.7 \%)$ as a yellow crystalline solid. IR (KBr, cm $\left.{ }^{-1}\right)$ : 3139.99(m), 3053.18(m), 2970.57(m), $2857.63(\mathrm{~m}), \quad 2770.29(\mathrm{w}), \quad 1588.44(\mathrm{~s}), \quad 1570.92(\mathrm{~d})$, $1514.39(\mathrm{~m}), \quad 1475.46(\mathrm{~s}), \quad 1435.06(\mathrm{~s}), \quad 1422.61(\mathrm{~m})$, $1353.43(\mathrm{~m}), \quad 1303.55(\mathrm{~m}), \quad 1275.00(\mathrm{~m}), \quad 1263.80(\mathrm{~m})$, $1148.39(\mathrm{~s}) \mathrm{cm}^{-1} .{ }^{1} \mathrm{H}$ NMR $(400 \mathrm{MHz}$, DMSO-d6) $\delta 12.45(\mathrm{~s}$, $1 \mathrm{H}), 8.59$ (dd, $J=3.6,2.3 \mathrm{~Hz}, 2 \mathrm{H}), 8.08(\mathrm{~s}, 1 \mathrm{H}), 7.93-7.81$ (m, 4H), $7.59(\mathrm{~s}, 1 \mathrm{H}), 7.41-7.25(\mathrm{~m}, 2 \mathrm{H})$. ESI-MS $\mathrm{m} / z(\%)$ : $281.8\left(\mathrm{M}^{+}+1\right)$. Anal. Calcd. For $\mathrm{C}_{14} \mathrm{H}_{11} \mathrm{~N}_{5} \mathrm{~S}$ : C, 59.77; $\mathrm{H}$, 3.94; N, 24.89; S, 11.40. Found: C, 59.69; H, 3.98; N, 24.92; S, 11.36. UV-Vis (DMSO, $\left.\lambda_{\max }, \mathrm{nm}\right): 255.0,340.0$.

4-(Pyridin-3-yl)-2-(2-(pyridin-4-ylmethylene)hydrazinyl)thiazole (L2) was prepared in a similar way to ligand L1, with 3-pyridine formaldehyde, 3-acetyl pyridine instead of 2-pyridine formaldehyde, 2-acetyl pyridine. L2, yellow power, yield $12.2 \mathrm{~g}(86.5 \%)$. IR $\left(\mathrm{KBr}, \mathrm{cm}^{-1}\right)$ : $3200.00(\mathrm{~m}), \quad 3079.41(\mathrm{~m}), \quad 2743.00(\mathrm{w}), \quad 1636.84(\mathrm{~m})$, 1599.83(s), 1561.72(s), 1499.00(s), 1462.66(s), 1407.26(m), $1375.20(\mathrm{~m}), \quad 1283.75(\mathrm{~m}), \quad 1212.35(\mathrm{~m}), \quad 1186.00(\mathrm{~m})$, 1169.97(m), 1123.58(m) cm ${ }^{-1} .{ }^{1} \mathrm{H}$ NMR (400 MHz, DMSOd6) $\delta 13.07(\mathrm{~s}, 1 \mathrm{H}), 9.14(\mathrm{~d}, J=1.6 \mathrm{~Hz}, 1 \mathrm{H}), 8.77(\mathrm{~d}$, $J=6.5 \mathrm{~Hz}, 2 \mathrm{H}), 8.61(\mathrm{dd}, J=5.0,1.5 \mathrm{~Hz}, 1 \mathrm{H}), 8.38(\mathrm{~d}$, $J=8.1 \mathrm{~Hz}, 1 \mathrm{H}), 8.13(\mathrm{~s}, 1 \mathrm{H}), 7.97(\mathrm{~d}, J=6.5 \mathrm{~Hz}, 1 \mathrm{H}), 7.76(\mathrm{~s}$, $1 \mathrm{H}), 7.62(\mathrm{dd}, J=8.0,5.0 \mathrm{~Hz}, 1 \mathrm{H})$. ESI-MS $\mathrm{m} / z(\%): 281.8$ $\left(\mathrm{M}^{+}+1\right)$. Anal. Calcd. For $\mathrm{C}_{14} \mathrm{H}_{11} \mathrm{~N}_{5} \mathrm{~S}: \mathrm{C}, 59.77 ; \mathrm{H}, 3.94 ; \mathrm{N}$, 24.89; S, 11.40. Found: C, 59.73; H, 3.97; N, 24.90; S, 11.36 . UV-Vis (DMSO, $\lambda_{\max }, \mathrm{nm}$ ): 255.0, 365.0.

2.3. Synthesis of Complexes 1-2. Complex 1. To a solution of 4-(pyridin-2-yl)-2-(2-(pyridin-2-ylmethylene)hydrazinyl)thiazole (L1) $(28 \mathrm{mg}, 0.1 \mathrm{mmol})$ in $\mathrm{DMF}(2 \mathrm{~mL}), \mathrm{Zn}(\mathrm{TsO})_{2}$ $(40.7 \mathrm{mg}, 0.1 \mathrm{mmol})$ in DMF $(2 \mathrm{~mL})$ was added slowly dropwise. The solution was filtered, and yellowish crystal $(42.2 \mathrm{mg})$ was obtained in a few days by the diffusion of diethyl ether in a wild-mouth bottle. The yield was $41.2 \%$. IR $\left(\mathrm{KBr}, \mathrm{cm}^{-1}\right)$ : 3216.90(m), 3071.80(m), 1605.36(s), 1592.50(s), 1574.47(d), 1494.73(m), 1470.91(s), 1445.51(m), 1432.01(m), 1376.73(m), 1311.65(m), 1284.21(m), 1155.66(s), 1107.48(s), 1029.73(m), 1005.69(s). ${ }^{1} \mathrm{H}$ NMR (400 MHz, DMSO-d6) $\delta$ $12.41(\mathrm{~s}, 1 \mathrm{H}), 8.60(\mathrm{~s}, 2 \mathrm{H}), 8.13(\mathrm{~s}, 2 \mathrm{H}), 7.90(\mathrm{~s}, 4 \mathrm{H}), 7.48(\mathrm{~d}$, $J=8.1 \mathrm{~Hz}, 2 \mathrm{H}), 7.39(\mathrm{~s}, 2 \mathrm{H}), 7.11(\mathrm{~d}, J=7.8 \mathrm{~Hz}, 2 \mathrm{H}), 2.29$ (s, $3 \mathrm{H})$. Anal. Calcd. For $\mathrm{C}_{42} \mathrm{H}_{36} \mathrm{~N}_{10} \mathrm{O}_{6} \mathrm{~S}_{4} \mathrm{Zn}$ : C, 51.98; H, 3.74; N, 


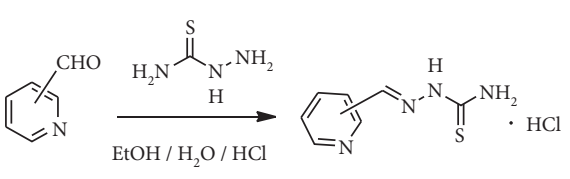

A

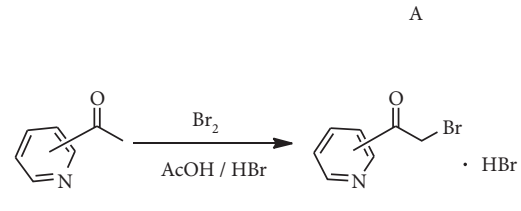

B

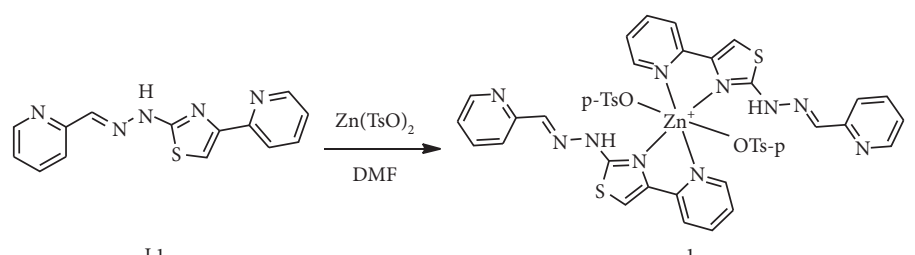

$\mathrm{L}$
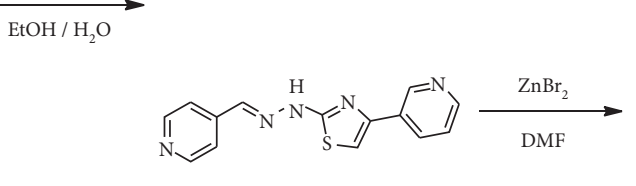

L2

SCHeme 1: Synthesis route of ligands and complexes 1-2.

TABLE 1: Crystallographic data and structure refinement summary for ligand L2 and complexes 1-2.

\begin{tabular}{|c|c|c|c|}
\hline & L2 & 1 & 2 \\
\hline Empirical formula & $\mathrm{C}_{14} \mathrm{H}_{11} \mathrm{~N}_{5} \mathrm{~S}$ & $\mathrm{C}_{42} \mathrm{H}_{36} \mathrm{~N}_{10} \mathrm{O}_{6} \mathrm{~S}_{4} \mathrm{Zn}$ & $\mathrm{C}_{20} \mathrm{H}_{26} \mathrm{Br}_{3} \mathrm{~N}_{7} \mathrm{O}_{2} \mathrm{SZn}$ \\
\hline $\mathrm{Mw}$ & 281.34 & 970.44 & 733.64 \\
\hline Crystal system & Monoclinic & Monoclinic & Monoclinic \\
\hline$a(\AA)$ & $8.5684(5)$ & $17.614(2)$ & $8.3543(5)$ \\
\hline$b(\AA)$ & $11.3512(6)$ & 20.6571(13) & $20.0129(13)$ \\
\hline$c(\AA)$ & $13.5596(8)$ & $17.620(2)$ & $16.2751(11)$ \\
\hline$\alpha\left(^{\circ}\right)$ & 90 & 90 & 90 \\
\hline$\beta\left(^{\circ}\right)$ & $107.149(6)$ & $112.260(15)$ & $94.611(6)$ \\
\hline$\gamma\left({ }^{\circ}\right)$ & 90 & 90 & 90 \\
\hline$V\left(\AA^{3}\right)$ & $1260.19(13)$ & $5933.2(12)$ & $2712.3(3)$ \\
\hline Space group & $\mathrm{P}_{2} / n$ & $\mathrm{P} 2{ }_{1} / c$ & $\mathrm{P} 2_{1} / n$ \\
\hline Density $\left(\mathrm{g} \cdot \mathrm{cm}^{-3}\right)$ & 1.483 & 1.046 & 1.797 \\
\hline$Z$ & 4 & 4 & 4 \\
\hline$\mu\left(\mathrm{mm}^{-1}\right)$ & 2.254 & 0.597 & 5.433 \\
\hline Temperature (K) & 100 & 100 & 100 \\
\hline$F(000)$ & 584 & 1857 & 1448 \\
\hline Crystal size $\left(\mathrm{mm}^{3}\right)$ & $0.12 \times 0.1 \times 0.08$ & $0.12 \times 0.11 \times 0.08$ & $0.12 \times 0.11 \times 0.1$ \\
\hline Radiation & $(\mathrm{Cu}-\mathrm{K} \alpha) 1.54184$ & $(\mathrm{Mo}-\mathrm{K} \alpha) 0.71073$ & $(\mathrm{Mo}-\mathrm{K} \alpha) 0.71073$ \\
\hline Index ranges & $\begin{array}{c}-10 \leq h \leq 8,-13 \leq k \leq 9 \\
-16 \leq l \leq 16\end{array}$ & $\begin{array}{c}-24 \leq h \leq 22,-28 \leq k \leq 22, \\
-23 \leq l \leq 24\end{array}$ & $\begin{array}{c}-10 \leq h \leq 11,-25 \leq k \leq 26 \\
-21 \leq l \leq 11\end{array}$ \\
\hline $\begin{array}{l}\theta \text { range for data collection } \\
\left({ }^{\circ}\right)\end{array}$ & $5.1730-72.8960$ & $2.2960-23.1730$ & $2.7030-26.5730$ \\
\hline Goodness-of-fit on $F^{2}$ & 1.028 & 1.025 & 1.047 \\
\hline Reflections collected & 4756 & 33034 & 14560 \\
\hline Independent reflections & $\begin{array}{l}2468\left[R_{\text {int }}=0.0399\right. \\
\left.R_{\text {sigma }}=0.0544\right]\end{array}$ & $\begin{array}{c}14148\left[R_{\text {int }}=0.1101,\right. \\
\left.R_{\text {sigma }}=0.2110\right]\end{array}$ & $6500\left[R_{\text {int }}=0.0455, R_{\text {sigma }}=0.0794\right]$ \\
\hline $\begin{array}{l}\text { Final } R \text { indexes }[I \geq 2 \sigma(I)] \\
R_{1}, \omega R_{2}\end{array}$ & $0.0430,0.0985$ & $0.1018,0.2400$ & $0.0571,0.1240$ \\
\hline $\begin{array}{l}\text { Final } R \text { indexes [all data] } \\
R_{1}, \omega R_{2}\end{array}$ & $0.0578,0.1063$ & $0.1860,0.2872$ & $0.0897,0.1391$ \\
\hline Data/restraints/parameters & $2468 / 0 / 181$ & $14148 / 85 / 498$ & $6500 / 101 / 398$ \\
\hline $\begin{array}{l}\text { Largest diff. peak/hole (e } \\
\AA^{-3} \text { ) }\end{array}$ & $0.685 /-0.490$ & $1.691 /-2.571$ & $0.86 /-1.72$ \\
\hline
\end{tabular}

14.43; S, 13.22. Found: C, 51.82; H, 3.72; N, 14.39; S, 13.18. UV-Vis (DMSO, $\left.\lambda_{\max }, \mathrm{nm}\right): 255.0,335.0$.

Complex 2. To a solution of 4-(pyridin-3-yl)-2-(2(pyridin-4-ylmethylene)hydrazinyl)thiazole (L2) $(28 \mathrm{mg}$, $0.1 \mathrm{mmol})$ in $\mathrm{CH}_{3} \mathrm{OH}(5 \mathrm{~mL}), \mathrm{ZnBr}_{2}(22.5 \mathrm{mg}, 0.1 \mathrm{mmol})$ in $\mathrm{CH}_{3} \mathrm{OH}(5 \mathrm{~mL})$ was added. The precipitate was filtered, washed with $\mathrm{CH}_{3} \mathrm{OH}$ three times, and redissolved with DMF $(5 \mathrm{~mL})$. By the diffusion of diethyl ether, the yellowish crystal ( $20.8 \mathrm{mg})$ was obtained in a few days. The yield was $44.8 \%$. IR $\left(\mathrm{KBr}, \mathrm{cm}^{-1}\right): 3245.21(\mathrm{~m}), 3096.59(\mathrm{~m})$, 1593.25(s), $\quad 1567.21(\mathrm{~s}), \quad 1500.00(\mathrm{~m}), \quad 1449.70(\mathrm{~s})$, $1410.93(\mathrm{~m}), \quad 1370.81(\mathrm{~s}), \quad 1306.35 \quad(\mathrm{~m}), \quad 1288.54(\mathrm{~s})$, 1246.09(d), 1192.70(m), 1161.98(s), 626.84(s). ${ }^{1} \mathrm{H}$ NMR (400 MHz, DMSO-d6) $\delta 12.96(\mathrm{~s}, 1 \mathrm{H}), 9.12(\mathrm{~s}, 1 \mathrm{H}), 8.73(\mathrm{~d}$, $J=6.4 \mathrm{~Hz}, 1 \mathrm{H}), 8.58(\mathrm{~d}, J=6.3 \mathrm{~Hz}, 1 \mathrm{H}), 8.32(\mathrm{~d}, J=7.7 \mathrm{~Hz}$, $1 \mathrm{H}), 8.10(\mathrm{~s}, 1 \mathrm{H}), 7.89(\mathrm{~d}, J=6.3 \mathrm{~Hz}, 1 \mathrm{H}), 7.71(\mathrm{~s}, 1 \mathrm{H}), 7.56$ 
TABLE 2: Infrared absorption peaks of the main functional groups on ligands L1 and L2 and complexes 1-3.

\begin{tabular}{lcccc}
\hline & L1 & L2 & 1 & 2 \\
\hline $\begin{array}{l}\text { Stretching vibration peak } \\
\text { (N-H) }\end{array}$ & $3139.99 \mathrm{~cm}^{-1}$ & $3200.00 \mathrm{~cm}^{-1}$ & $3216.90 \mathrm{~cm}^{-1}$ & $3245.21 \mathrm{~cm}^{-1}$ \\
$\begin{array}{l}\text { Skeleton vibration peak } \\
\text { (pyridine) }\end{array}$ & $1353.43,1588.44,1514.39$, & $1462.66,1499.00,1599.83$, & $1592.50,1376.73 \mathrm{~cm}^{-1}$ & $1567.21,1593.25,1500.00$, \\
$\begin{array}{l}\text { Skeleton vibration peak } \\
\text { (Thiazole) }\end{array}$ & $1475.46 \mathrm{~cm}^{-1}$ & $1636.84 \mathrm{~cm}^{-1}$ & $1449.70 \mathrm{~cm}^{-1}$ & $1410.93,1370.81$, \\
$\begin{array}{l}\text { Stretching vibration peak } \\
\text { (C-H on pyridine) }\end{array}$ & $1422.61 \mathrm{~cm}^{-1}$ & $1561.72,1407.26$, & $1470.91,1432.01$, & $1306.35 \mathrm{~cm}^{-1}$ \\
$\begin{array}{l}\text { Stretching vibration peak } \\
\text { (C=N on ring) }\end{array}$ & $1303.55,1275.00 \mathrm{~cm}^{-1}$ & $1375.20 \mathrm{~cm}^{-1}$ & $131.65 \mathrm{~cm}^{-1}$ & $3096.59 \mathrm{~cm}^{-1}$ \\
$\begin{array}{l}\text { In-plane oscillations peak } \\
\text { (C-H on pyridine and }\end{array}$ & $1100-400 \mathrm{~cm}^{-1}$ & $3079.41 \mathrm{~cm}^{-1}$ & $3071.80 \mathrm{~cm}^{-1}$ & $1212.35 \mathrm{~cm}^{-1}$ \\
thiazole ring) & & $1100-400 \mathrm{~cm}^{-1}$ & $1284.21 \mathrm{~cm}^{-1}$ & $1288.54,1246.09 \mathrm{~cm}^{-1}$ \\
\hline
\end{tabular}

TABLE 3: Selected bond lengths $(\AA)$ and bond angles $\left(^{\circ}\right)$ of L2.

\begin{tabular}{lc}
\hline Bond & Dist. \\
$\mathrm{S}(1)-\mathrm{C}(7)$ & $1.743(2)$ \\
$\mathrm{S}(1)-\mathrm{C}(14)$ & $1.724(2)$ \\
$\mathrm{N}(4)-\mathrm{C}(8)$ & $1.390(3)$ \\
$\mathrm{N}(3)-\mathrm{C}(7)$ & $1.360(3)$ \\
$\mathrm{N}(5)-\mathrm{C}(10)$ & $1.345(3)$ \\
$\mathrm{N}(5)-\mathrm{C}(11)$ & $1.336(3)$ \\
$\mathrm{N}(4)-\mathrm{C}(7)$ & $1.303(3)$ \\
$\mathrm{N}(2)-\mathrm{C}(6)$ & $1.279(3)$ \\
$\mathrm{N}(3)-\mathrm{N}(2)$ & $1.360(2)$ \\
\hline $\mathrm{Angle}$ & $\left(^{\circ}\right)$ \\
$\mathrm{C}(14)-\mathrm{S}(1)-\mathrm{C}(7)$ & $88.1(1)$ \\
$\mathrm{C}(7)-\mathrm{N}(4)-\mathrm{C}(8)$ & $109.65(18)$ \\
$\mathrm{N}(2)-\mathrm{N}(3)-\mathrm{H}(3)$ & 121.300 \\
$\mathrm{C}(13)-\mathrm{C}(9)-\mathrm{C}(8)-\mathrm{N}(4)$ & 172.59 \\
$\mathrm{~N}(3)-\mathrm{C}(7)-\mathrm{S}(1)$ & $120.47(15)$ \\
$\mathrm{N}(2)-\mathrm{C}(6)-\mathrm{C}(5)$ & $120.4(2)$ \\
$\mathrm{N}(2)-\mathrm{C}(6)-\mathrm{H}(6)$ & 119.800 \\
$(10)-\mathrm{C}(9)-\mathrm{C}(8)-\mathrm{C}(14)$ & 174.37 \\
$\mathrm{~N}(2)-\mathrm{N} 3-\mathrm{C} 7$ & $117.43(18)$ \\
$\mathrm{C}(7)-\mathrm{N}(3)-\mathrm{H}(3)$ & 121.300 \\
$\mathrm{C}(6)-\mathrm{N}(2)-\mathrm{N}(3)$ & $116.83(18)$ \\
\hline
\end{tabular}

(dd, $J=8.3, \quad 5.0 \mathrm{~Hz}, 1 \mathrm{H})$. Anal. Calcd. For $\mathrm{C}_{20} \mathrm{H}_{26} \mathrm{Br}_{3} \mathrm{~N}_{7} \mathrm{O}_{2} \mathrm{SZn}: \mathrm{C}, 32.74 ; \mathrm{H}, 3.57 ; \mathrm{N}, 13.36 ; \mathrm{S}, 4.37$. Found: C, 32.79; H, 3.55; N, 13.27; S, 4.35. UV-Vis (DMSO, $\left.\lambda_{\max }, \mathrm{nm}\right): 260.4,370.0$.

2.4. X-Ray Structure Determination. Crystals were selected appropriately and mounted on a glass fiber in a random orientation. A single crystal of ligand $\mathbf{L} \mathbf{1}$ was mounted on a Bruker Smart Apex-CCD diffractometer with $\mathrm{CuK} \alpha$ radiation $(\lambda=1.54178 \AA)$ at $293 \mathrm{~K}$, while the other crystals were carried out on an Agilent SuperNova diffractometer with $\mathrm{CuK} \alpha$ radiation $(\lambda=1.54178 \AA)$ and with $\mathrm{MoK} \alpha$ radiation $(\lambda=0.71073 \AA)$ at $100 \mathrm{~K}$, respectively. The crystallographic data and structure refinement summary of ligands L1, L2 and complexes 1-2 are listed in Table 1. Using OLEX2 [16], the structure was solved by direct methods using the SHELXS program [17] and refined by full-matrix leastsquares techniques SHELXL-2014 [18] on $F^{2}$. All nonhydrogen atoms were refined anisotropically. DIAMOND was used for molecular graphics [19].

2.5. Antimicrobial Activity Studies. Qualitative analysis for screening of antibacterial activity was carried out by the microplate reader method [20-22]. Mueller-Hinton agar plates were seeded with indicator bacteria, Escherichia coli (E. coli, ATCC 25922), Staphylococcus aureus (S. aureus, CMCC(B) 26003), Salmonella typhimurium (S. typhimurium, CMCC(B) 50071), Bacillus subtilis (B. subtilis, ATCC 6633), Shigella flexneri (Sh. flexneri, CMCC(B) 51572), Vibrio parahaemolyticus (V. parahaemolyticus, ATCC 17802), and Pseudomonas aeruginosa ( $P$. aeruginosa, ATCC 9027), and cultured for $24 \mathrm{~h}$ at $37^{\circ} \mathrm{C}$. Plates were inoculated with bacteria adjusted to $0.5 \mathrm{McF}$ arland turbidity standards $\left(10^{8} \mathrm{cfu} / \mathrm{mL}\right)$. All compounds were dissolved in DMSO $(100 \mu \mathrm{g} / \mathrm{mL}$ as an initial concentration) and tested against the ten pathogenic bacteria strains for their inhibitory activity. The antimicrobial activity of the compounds was expressed as the bacteriostatic rate (\%) and determined by the absorbance of the bacterial samples using an enzyme-labeled instrument. Subsequently, compounds with high inhibitory rate $(+++)$ were selected for minimum inhibitory concentration (MIC) determination using double dilution method with concentrations ranging from 3.125 to $50 \mu \mathrm{g} / \mathrm{mL}$. The MIC was recorded as the lowest concentration at which inhibitory rate was greater than $95 \%$. As a blank group, only DMSO was added to the wells, and Ciprofloxacin was used as positive control for antibacterial activity. All tests and analyses were run in duplicate, and the results obtained were averaged. The percentage inhibition was calculated using the following equation:

$$
\operatorname{inhibition}(\%)=\frac{A b s_{\text {blank }}-\left(A b s_{\text {sample }}-A b s_{\text {control }}\right)}{A b s_{\text {blank }}} \times 100 \text {, }
$$

where $A b s_{\text {blank }}$ is the absorbance of DMSO + blank medium, $A b s_{\text {control }}$ is the absorbance of sample + blank medium, and $A b s_{\text {sample }}$ is the absorbance of sample (test samples/standard) + bacterial suspension in medium. 


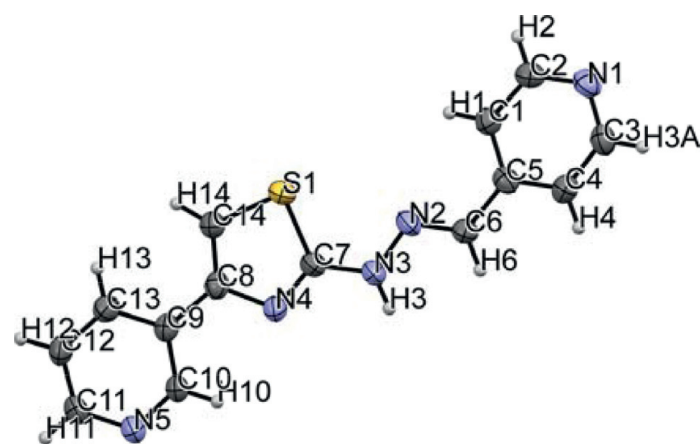

(a)

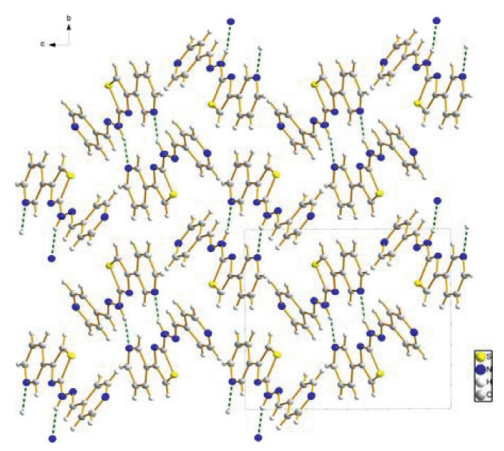

(b)

Figure 1: (a) The structure of ligand L2. (b) Molecular accumulation figure viewed along a-axis in L2 (green lines represent the H-bonds).

TABLE 4: Hydrogen bonds for the L2 ( $\mathrm{A}$ and $\left.{ }^{\circ}\right)$.

\begin{tabular}{lcccc}
\hline $\mathrm{D}-\mathrm{H} \cdots \mathrm{A}$ & $\mathrm{D}-\mathrm{H}$ & $\mathrm{H} \cdots \mathrm{A}$ & $\mathrm{D} \cdots \mathrm{A}$ & \\
\hline $\mathrm{N}(3)-\mathrm{H}(3) \cdots \mathrm{N}(5)$ & 0.8800 & 2.0440 & 2.864 & $\mathrm{D}-\mathrm{H} \cdots \mathrm{A}$ \\
\hline
\end{tabular}

2.6. Antitumor Activity Studies. The viability of the cell lines was tested using 3-(4,5-dimethylthiazol-2-yl)-2,5-diphenyltetrazolium bromide (MTT) assay [23, 24]. The compounds were dissolved in DMSO and diluted with water to the required concentration $(160 \mu \mathrm{g} / \mathrm{mL}, 80 \mu \mathrm{g} / \mathrm{mL}, 40 \mu \mathrm{g} / \mathrm{mL}$, $20 \mu \mathrm{g} / \mathrm{mL}, \quad 10 \mu \mathrm{g} / \mathrm{mL}, \quad 5 \mu \mathrm{g} / \mathrm{mL}, 0 \mu \mathrm{g} / \mathrm{mL})$. Human lung cancer cells (A549), human breast cancer cells (BT-20), human ovarian cell cells (MCF-7), and human osteosarcoma cells (U20S) cells were kindly provided by Stem Cell Bank, Chinese Academy of Sciences, and were plated in 96-multiwell plates (104 cells/well) for 24 hours before treatment with different concentrations of complexes to allow attachment of cell to the wall of the plates. Then, the cells were cultured using MEM, DMEM, F-12K, and DMEM/F12 (GIBCO) culture medium containing $10 \%$ fetal bovine serum in a $5 \%$ (volume fraction) $\mathrm{CO}_{2}, 37^{\circ} \mathrm{C}$ saturated humidity incubator for 48 hours, respectively. Cells were fixed, washed, and stained with MTT. Cell growth inhibition was determined by measuring the absorbance of each well at $570 \mathrm{~nm}$ with a Tecan Infinite M1000 Pro Microplate Reader (Männedorf, Switzerland). GraphPad Prism version 7.0 program was used for data processing, and IC50 was obtained by fitting the nonlinear regression model with $\mathrm{S}$-shaped dose response in the program.

\section{Results and Discussion}

3.1. Solution Stability of Complexes 1-2. The essential prerequisite for the biological evaluation of metal complexes is their stability in solution. In the light of this fact, complexes 1-2 were dissolved in DMSO and DMSO-d6 (a solvent used for the preparation of stock solutions for biological evaluation), and their UV-Vis and NMR spectra, respectively, were recorded immediately after dissolution, as well as after $48 \mathrm{~h}$ of standing in the dark at ambient temperature. From NMR measurements (Figure S1), it can be concluded that the corresponding $\mathrm{N}$-pyridine and $\mathrm{N}$-thiazole remained coordinated to the $\mathrm{Zn}$ (II) ion during $48 \mathrm{~h}$ and that DMSO
Table 5: Selected bond lengths $(\AA)$ and bond angles $\left({ }^{\circ}\right)$ of complex 1.

\begin{tabular}{lc}
\hline Bond & Dist. \\
$\mathrm{Zn}(1)-\mathrm{N}(2)$ & $2.089(6)$ \\
$\mathrm{Zn}(1)-\mathrm{O}(4)$ & $2.117(5)$ \\
$\mathrm{Zn}(1)-\mathrm{N}(6)$ & $2.175(5)$ \\
$\mathrm{Zn}(1)-\mathrm{O}(1)$ & $2.153(4)$ \\
$\mathrm{Zn}(1)-\mathrm{N}(7)$ & $2.085(5)$ \\
$\mathrm{Zn}(1)-\mathrm{N}(1)$ & $2.140(6)$ \\
$\mathrm{S}(1)-\mathrm{O}(1)$ & $1.487(4)$ \\
$\mathrm{S}(2)-\mathrm{O}(4)$ & $1.487(5)$ \\
$\mathrm{N}(9)-\mathrm{N}(8)$ & $1.368(7)$ \\
\hline $\mathrm{Angle}$ & $\left({ }^{\circ}\right)$ \\
$\mathrm{N}(2)-\mathrm{Zn}(1)-\mathrm{O}(4)$ & $90.2(2)$ \\
$\mathrm{N}(2)-\mathrm{Zn}(1)-\mathrm{N}(6)$ & $97.4(2)$ \\
$\mathrm{N}(2)-\mathrm{Zn}(1)-\mathrm{O}(1)$ & $94.40(19)$ \\
$\mathrm{N}(7)-\mathrm{Zn}(1)-\mathrm{O}(4)$ & $95.46(19)$ \\
$\mathrm{N}(7)-\mathrm{Zn}(1)-\mathrm{N}(6)$ & $78.01(18)$ \\
$\mathrm{N}(2)-\mathrm{Zn}(1)-\mathrm{N}(1)$ & $78.0(2)$ \\
$\mathrm{O}(4)-\mathrm{Zn}(1)-\mathrm{N}(6)$ & $91.01(18)$ \\
$\mathrm{O}(4)-\mathrm{Zn}(1)-\mathrm{O}(1)$ & $87.19(16)$ \\
$\mathrm{N}(7)-\mathrm{Zn}(1)-\mathrm{O}(1)$ & $90.43(17)$ \\
$\mathrm{N}(7)-\mathrm{Zn}(1)-\mathrm{N}(1)$ & $96.8(2)$ \\
$\mathrm{O}(4)-\mathrm{Zn}(1)-\mathrm{N}(1)$ & $166.75(18)$ \\
$\mathrm{O}(1)-\mathrm{Zn}(1)-\mathrm{N}(6)$ & $168.09(16)$ \\
$\mathrm{N}(7)-\mathrm{Zn}(1)-\mathrm{N}(2)$ & $172.8(2)$ \\
$\mathrm{N}(1)-\mathrm{Zn}(1)-\mathrm{N}(6)$ & $96.3(2)$ \\
$\mathrm{N}(1)-\mathrm{Zn}(1)-\mathrm{O}(1)$ & $87.8(2)$ \\
\hline &
\end{tabular}

coordination did not occur. In the UV-Vis spectra (Figure S3), the shape of spectra and position of the absorption maxima $\left(\lambda_{\max }=255.0,335.0 \mathrm{~nm}\right.$ for complex $1 ; \lambda_{\max }=260.4$, $370.0 \mathrm{~nm}$ for complex 2) remained unmodified. Taken together, obtained spectroscopic data indicated the sufficient stability of complexes 1-2 in DMSO solution.

3.2. FTIR Spectral Elucidation. The infrared absorption peaks of the main functional groups on ligands $\mathbf{L} \mathbf{1}$ and $\mathbf{L} 2$ and complexes 1-3 are listed in Table 2. Additionally, as 


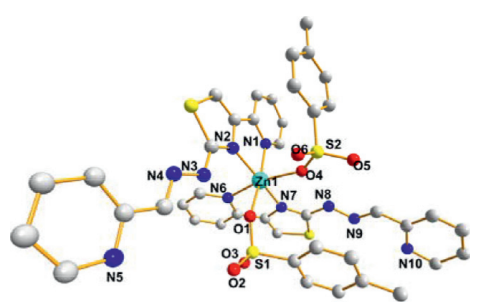

(a)

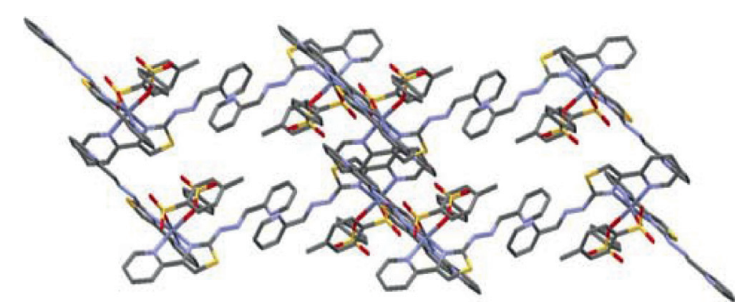

(b)

FIgURE 2: (a) View of the coordination environment of $\mathrm{Zn}(\mathrm{II})$ ions in 1. (b) Molecular accumulation figure viewed along b-axis in 1.

shown in Figure S2, the peak at $2970.57 \mathrm{~cm}^{-1}$ was the stretching vibration peak of the $\mathrm{C}-\mathrm{H}$ bond in the $\mathrm{N}=\mathrm{C}-\mathrm{H}$ group, and the peaks at 2857.63 and $2770.29 \mathrm{~cm}^{-1}$ belonged to the stretching vibration peak of the $\mathrm{C}-\mathrm{H}$ bond on the thiazole ring, while that at $1263.80 \mathrm{~cm}^{-1}$ was the stretching vibration peak of the Schiff base $\mathrm{C}=\mathrm{N}$ bond. The peaks at $1148.39 \mathrm{~cm}^{-1}$ were attributed to the stretching vibration of the $\mathrm{C}-\mathrm{N}$ bond. In compound $\mathrm{L} 2$, the peak at $2743.00 \mathrm{~cm}^{-1}$ belonged to the stretching vibration peak of the $\mathrm{C}-\mathrm{H}$ bond on the thiazole ring, whereas that at $1283.75 \mathrm{~cm}^{-1}$ was the stretching vibration peak of the Schiff base $\mathrm{C}=\mathrm{N}$ bond. The peaks at $1186.00,1123.58$, and $1169.97 \mathrm{~cm}^{-1}$ were attributed to the stretching vibration of the $\mathrm{C}-\mathrm{N}$ bond. In complex 1, the peaks at 1605.36, 1574.47, 1445.51, and $1494.73 \mathrm{~cm}^{-1}$ were caused by the skeleton vibration of the benzene ring. The peak at $1155.66-1005.69 \mathrm{~cm}^{-1}$ belonged to the antisymmetric stretching vibration and symmetric stretching vibration of the $\mathrm{SO}_{3}$ group in p-toluene sulfonate. In complex 2 , the stretching vibration peaks of the $\mathrm{C}-\mathrm{N}$ bond were 1192.70 and $1161.98 \mathrm{~cm}^{-1}$, whereas $626.84 \mathrm{~cm}^{-1}$ might belong to the characteristic absorption peak of $\mathrm{Zn}-\mathrm{Br}$.

3.3. X-Ray Crystal Structure. Suitable single crystals of ligand L2 and complexes 1-2 for X-ray diffraction studies were obtained by the diffusion of diethyl ether into a DMF solution at room temperature. Ligand $\mathbf{L} 2$ was crystallized in a monoclinic system, and the spatial group was $\mathrm{P} 2_{1} / n$. The selected bond lengths and bond angles of $\mathbf{L} 2$ are listed in Table 3. The $\mathrm{N}(3)-\mathrm{N}(2)$ bond $(1.360(2) \AA)$ has the same length as the $\mathrm{N}(3)-\mathrm{C}(7)$ bond. The molecular structure of L2 and its packing diagram are depicted in Figure 1. In the crystal of $\mathbf{L} 2$, the molecule is in the E-conformation, and the supramolecular arrangement is directed mainly by strong $\mathrm{N}(3)-\mathrm{H}(3) \cdots \mathrm{N}(5)$ hydrogen bonds between two molecules (Table 4). The torsion angles of $\mathrm{C}(13)-\mathrm{C}(9)-\mathrm{C}(8)-\mathrm{N}(4)$ $\left(172.59^{\circ}\right)$ and $\mathrm{C}(10)-\mathrm{C}(9)-\mathrm{C}(8)-\mathrm{C}(14)\left(174.37^{\circ}\right)$ indicate that the thiazole ring is almost coplanar with the neighboring pyridine ring.

Complex 1 crystallized in a monoclinic unit cell, $\mathrm{P} 2_{1} / c$ space group. The selected bond lengths and bond angles of complex $\mathbf{1}$ are listed in Table 5. As shown in Figure 2, the $\mathrm{Zn}$ (II) atom occupies the center of inversion with a coordination model of $\mathrm{ML}_{2}$, and it is coordinated by four nitrogen atoms from two ligands, two oxygen atoms from two
TABLe 6: Selected bond lengths $(\AA)$ and bond angles $\left({ }^{\circ}\right)$ of complex 2.

\begin{tabular}{lc}
\hline Bond & Dist. \\
$\operatorname{Zn}(1)-\operatorname{Br}(1)$ & $2.3834(8)$ \\
$\operatorname{Zn}(1)-\operatorname{Br}(3)$ & $2.3715(9)$ \\
$\operatorname{Zn}(1)-\operatorname{Br}(2)$ & $2.3878(9)$ \\
$\operatorname{Zn}(1)-\mathrm{N}(1)$ & $2.073(4)$ \\
$\mathrm{S}(1)-\mathrm{C}(7)$ & $1.726(5)$ \\
$\mathrm{S}(1)-\mathrm{C}(8)$ & $1.740(6)$ \\
\hline Angle & $\left(^{\circ}\right)$ \\
$\operatorname{Br}(1)-\operatorname{Zn}(1)-\operatorname{Br}(2)$ & $112.75(3)$ \\
$\operatorname{Br}(3)-\operatorname{Zn}(1)-\operatorname{Br}(1)$ & $110.68(3)$ \\
$\operatorname{Br}(3)-\operatorname{Zn}(1)-\operatorname{Br}(2)$ & $112.54(3)$ \\
$\mathrm{N} 1-\operatorname{Zn}(1)-\operatorname{Br}(1)$ & $109.01(12)$ \\
$\mathrm{N} 1-\operatorname{Zn}(1)-\operatorname{Br}(3)$ & $105.75(12)$ \\
$\mathrm{N} 1-\operatorname{Zn}(1)-\operatorname{Br}(2)$ & $105.70(12)$ \\
\hline
\end{tabular}

p-toluene sulfonic acid ions. The distances of $\mathrm{Zn}(1)-\mathrm{O}(1)$ and $\mathrm{Zn}(1)-\mathrm{O}(4)$ are 2.153(4) and 2.117(5), respectively. The distances of $\mathrm{Zn}(1)-\mathrm{N}(1), \mathrm{Zn}(1)-\mathrm{N}(2), \mathrm{Zn}(1)-\mathrm{N}(6)$, and $\mathrm{Zn}(1)-\mathrm{N}(7)$ are 2.140(6), 2.089(6), 2.175(5), and 2.085(5) respectively. The $\mathrm{S} 1$ atom in thiazole ring was not coordinated with the metal ion. The $\mathrm{N}(2)-\mathrm{Zn}(1)-\mathrm{O}(4), \mathrm{N}(2)-$ $\mathrm{Zn}(1)-\mathrm{N}(6)$, and $\mathrm{N}(7)-\mathrm{Zn}(1)-\mathrm{O}(1)$ bond angles are all nearly $90^{\circ}$, indicating that the complexes have nearly perfect hexahedron geometry as expected. The bond distances and angle values of $\mathbf{2}$ are in good agreement with the related $\mathrm{Zn}$ (II) complexes.

The selected bond lengths and angles for complex 2 are summarized in Table 6. A deformed tetrahedron geometry around the central atom is confirmed by the $\mathrm{Br}(1)-\mathrm{Zn}(1)-$ $\operatorname{Br}(2), \operatorname{Br}(3)-\operatorname{Zn}(1)-\operatorname{Br}(2), \quad \operatorname{Br}(1)-\mathrm{Zn}(1)-\mathrm{Br}(3)$, and $\mathrm{N}(1)-$ $\mathrm{Zn}(1)-\mathrm{Br}(1)$ bite angles, which differ a little as expected for atoms coordinated in cis-positions, and also by the $\mathrm{Zn}(1)-\mathrm{N} 1$ bond (2.073(4)), which is slightly shorter than the $\mathrm{Zn}(1)-\mathrm{Br}$ bonds (2.3834(8), 2.3878(9), 2.3715(9) $\mathrm{A}$, respectively) due to the smaller covalent radius of nitrogen. Nevertheless, the bond distances around the $\mathrm{Zn}(\mathrm{II})$ atom are similar to those observed in similar $\mathrm{Zn}$ (II) complexes as reported in the Crystallography Open Database [25]. Two disordered DMF molecules were not involved in the coordinate system with $35 \%$ and $45 \%$ occupancy factors, respectively (Figure 3, Table 7). Additionally, intramolecular hydrogen bonds $\mathrm{N}(3)-\mathrm{H}(3) \cdots \mathrm{O}(1)$ and $\mathrm{N}(3)-$ $\mathrm{H}(3) \cdots \mathrm{O}(1 \mathrm{~A})$ were observed between ligand $\mathbf{L} \mathbf{2}$ and one disordered DMF molecule with the distance of 2.793(16) and 2.740(3) $\AA$ in the crystal structure. 


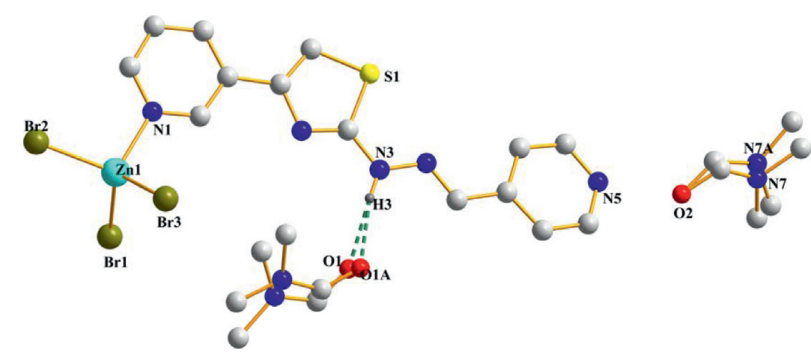

FIgURE 3: The structure of 2 (green lines represent the H-bonds).

TABLE 7: Hydrogen bonds for the complex $2\left(\AA\right.$ and $\left.{ }^{\circ}\right)$.

\begin{tabular}{lcccc}
\hline $\mathrm{D}-\mathrm{H} \cdots \mathrm{A}$ & $\mathrm{D}-\mathrm{H}$ & $\mathrm{H} \cdots \mathrm{A}$ & $\mathrm{D} \cdots \mathrm{A}$ & $\mathrm{D}-\mathrm{H} \cdots \mathrm{A}$ \\
\hline $\mathrm{N}(3)-\mathrm{H}(3) \cdots \mathrm{O}(1)$ & 0.8800 & 1.9800 & $2.793(16)$ & 153.500 \\
$\mathrm{~N}(3)-\mathrm{H}(3) \cdots \mathrm{O}(1 \mathrm{~A})$ & 0.8800 & 1.9000 & $2.740(3)$ & 160.400 \\
\hline
\end{tabular}

TABLE 8: Bactericidal activity screening test levels of the ligands and complexes $(100 \mu \mathrm{g} / \mathrm{mL})^{\mathrm{a}}$.

\begin{tabular}{|c|c|c|c|c|c|c|c|}
\hline \multirow{2}{*}{ Compounds } & \multicolumn{7}{|c|}{ Inhibition ratio (\%) $\left(\right.$ Levels $\left.^{\mathrm{c}}\right)$} \\
\hline & E. coli $^{\mathrm{b}}$ & S. aureus $^{\mathrm{b}}$ & S. typhimurium ${ }^{\mathrm{b}}$ & B. subtilis ${ }^{\mathrm{b}}$ & Sh. flexneri ${ }^{\mathrm{b}}$ & V. parahaemolyticus ${ }^{\mathrm{b}}$ & P. aeruginosa ${ }^{\mathrm{b}}$ \\
\hline L1 & $\begin{array}{l}84.9 \\
(++)\end{array}$ & $\begin{array}{l}81.5 \\
(++)\end{array}$ & $\begin{array}{l}77.2 \\
(++)\end{array}$ & $\begin{array}{l}73.9 \\
(++)\end{array}$ & $\begin{array}{c}96.3 \\
(+++)\end{array}$ & $\begin{array}{l}74.8 \\
(++)\end{array}$ & $\begin{array}{c}97.1 \\
(+++)\end{array}$ \\
\hline $\mathbf{L} 2$ & $\begin{array}{c}101.7 \\
(+)\end{array}$ & $\begin{array}{l}55.4 \\
(-)\end{array}$ & $\begin{array}{l}77.0 \\
(+)\end{array}$ & $\begin{array}{c}99.1 \\
(+++)\end{array}$ & $\begin{array}{c}98.7 \\
(+++)\end{array}$ & $\begin{array}{l}14.3 \\
(-)\end{array}$ & $\begin{array}{l}79.2 \\
(+)\end{array}$ \\
\hline 1 & $\begin{array}{l}73.9 \\
(++)\end{array}$ & $\begin{array}{c}97.3 \\
(+++)\end{array}$ & $\begin{array}{c}99.7 \\
(+++)\end{array}$ & $\begin{array}{l}102.0 \\
(+++)\end{array}$ & $\begin{array}{c}99.2 \\
(+++)\end{array}$ & $\begin{array}{c}98.7 \\
(+++)\end{array}$ & $\begin{array}{l}43.8 \\
(-)\end{array}$ \\
\hline 2 & $\begin{array}{l}102.3 \\
(+++)\end{array}$ & $\begin{array}{l}102.2 \\
(+++)\end{array}$ & $\begin{array}{c}96.3 \\
(+++)\end{array}$ & $\begin{array}{c}54.6 \\
(+++)\end{array}$ & $\begin{array}{l}100.0 \\
(+++)\end{array}$ & $\begin{array}{l}40.4 \\
(-)\end{array}$ & $\begin{array}{l}101.3 \\
(+++)\end{array}$ \\
\hline
\end{tabular}

${ }^{a}$ Bactericidal activity is revealed by the percentage of complexes against bacterial strain. ${ }^{b}$ Escherichia coli (E. coli, ATCC 25922), Staphylococcus aureus (S. aureus, CMCC(B) 26003), Salmonella typhimurium (S. typhimurium, CMCC(B) 50071), Bacillus subtilis (B. subtilis, ATCC 6633), Shigella flexneri (Sh. flexneri, CMCC(B) 51572), Vibrio parahaemolyticus (V. parahaemolyticus, ATCC 17802), Pseudomonas aeruginosa (P. aeruginosa, ATCC 9027). ${ }^{\mathrm{C} A c t i v i t y}$ levels; +++ $\geq 90 \% ;++\geq 70-89 \% ;+\geq 50-69 \% ;-<50 \%$.

TABLe 9: Tests of MIC $(\mu \mathrm{g} / \mathrm{mL})$ of the ligands and complexes against bacterial strains ${ }^{\mathrm{a}}$.

\begin{tabular}{lccccccc}
\hline \multirow{2}{*}{ Compounds } & & \multicolumn{5}{c}{ MIC $\left(\mu \mathrm{g} \cdot \mathrm{mL}^{-1}\right)$} \\
& E. coli & S. aureus & S. typhimurium & B. subtilis & Sh. flexneri & V. parahaemolyticus & P. aeruginosa \\
\hline CIPRO $^{\mathrm{b}}$ & 12.5 & 6.25 & 12.5 & 6.25 & 3.13 & 3.13 & -25 \\
L1 & - & - & - & - & 50.0 & - & 100.0 \\
L2 & 12.5 & - & - & 5.25 & 100 & - & - \\
$\mathbf{1}$ & - & 12.5 & 12.5 & - & 3.13 & - & 6.25 \\
$\mathbf{2}$ & 3.13 & 12.5 & &
\end{tabular}

${ }^{\mathrm{a}}$ Results are expressed as the minimum inhibitory concentration (MIC). ${ }^{\mathrm{b}}$ Ciprofloxacin (CIPRO).

3.4. Biological Activity. The antibacterial activity of the ligands and complexes was presented as inhibition rate, and those with high inhibitory rate $(+++)$ were selected for minimum inhibitory concentration (MIC) determination. As shown in Table 8, the complexes had a wider broad spectrum and stronger antibacterial property than the ligands, and such enhanced activity of metal chelates is due to faster diffusion of metal complexes as a whole through the cell membrane or due to combined activity effect of the metal and the ligand. To further measure the MIC, CIPRO was used as the positive control. Compared with the CIPRO, complex 2 had a better or the same inhibitory effect on E. coli, Sh. flexneri, and $P$. aeruginosa with the MIC of $3.13 \mu \mathrm{g} \cdot \mathrm{mL}^{-1}, 3.13 \mu \mathrm{g} \cdot \mathrm{mL}^{-1}$, and $6.25 \mu \mathrm{g} \cdot \mathrm{mL}^{-1}$, respectively, while complex 1 held a stronger inhibitory effect on S. typhimurium and B. subtilis with the MIC of $6.25 \mu \mathrm{g} \cdot \mathrm{mL}^{-1}$ and $3.13 \mu \mathrm{g} \cdot \mathrm{mL}^{-1}$, respectively (Table 9). These results indicated that the complexes possess antibacterial activity inhibiting multiplication process of the microbes by blocking their active sites [26, 27].

The in vitro antitumor activity of the compounds against human lung cancer cells (A549), human breast cancer cells 
TABle 10: Tests of $\mathrm{IC}_{50}(\mu \mathrm{g} / \mathrm{mL})$ of the ligands and complexes against cancer cells ${ }^{\mathrm{a}}$.

\begin{tabular}{lcccc}
\hline \multirow{2}{*}{ Compounds } & \multicolumn{4}{c}{$\mathrm{IC}_{50} \pm \mathrm{SD}\left(\mu \mathrm{g} \cdot \mathrm{mL}^{-1}\right)$} \\
& $\mathrm{A}^{-1} 49^{\mathrm{b}}$ & $\mathrm{BT}^{\mathrm{b}}-20^{\mathrm{b}}$ & $\mathrm{MCF}-7^{\mathrm{b}}$ & $\mathrm{U}^{2} 2 S^{\mathrm{b}}$ \\
\hline L1 & $30.16 \pm 3.45$ & $45.30 \pm 4.84$ & $26.50 \pm 4.49$ & $52.00 \pm 4.37$ \\
L2 & $36.72 \pm 2.36$ & $23.25 \pm 1.63$ & $21.33 \pm 3.81$ & $38.22 \pm 4.12$ \\
$\mathbf{1}$ & $7.43 \pm 1.55$ & $12.23 \pm 2.11$ & $17.35 \pm 3.23$ & $9.78 \pm 1.24$ \\
$\mathbf{2}$ & $4.48 \pm 0.68$ & $8.23 \pm 1.02$ & $6.38 \pm 0.29$ & $9.52 \pm 0.93$ \\
\hline
\end{tabular}

${ }^{\mathrm{a}}$ Results are expressed as the half maximal inhibitory concentration ( $\mathrm{IC}_{50}$ ). ${ }^{b}$ Human lung cancer cells (A549), human breast cancer cells (BT-20), human ovarian cancer cells (MCF-7), human osteosarcoma cells (U20S).

(BT-20), human ovarian cancer cells (MCF-7), and human osteosarcoma cells (U20S) was measured via MTT assay. In general, the complexes showed a stronger antitumor activity than the corresponding ligands (Table 10). Between the two complexes, complex 2 exerted a more effective antitumor activity with the lower $\mathrm{IC}_{50}$ value. Among the four cancer cell lines, complex 2 had the most significant effect on A549 with the $\mathrm{IC}_{50}$ value of $4.48 \mu \mathrm{g} / \mathrm{mL}$. The result indicated the enhancement of the antitumor activity upon coordination. The enhancement of antitumor activity may be attributed to the fact that the positive charge of the metal increased the acidity of coordinated ligand that bears protons, leading to stronger hydrogen bonds which enhanced the biological activity [28]. Despite the conformed antitumor activity, a detailed molecular mechanism against cancer cell lines of the ligands and the complexes remains to be further elucidated.

\section{Conclusion}

In this paper, We have reported the preparation, characterization, and biological activities of new thiazole-hydrazone derivatives based on pyridine and their two $\mathrm{Zn}$ (II) complexes. Single-crystal X-ray diffraction analysis indicated that both ligand L2 and complexes 1-2 had mononuclear molecular structure. The in vitro antimicrobial activity of the complexes was screened using the microplate reader method, and in vitro antitumor activities of the complexes were evaluated by MTT. The results showed that the complexes coordinated with $\mathrm{Zn}^{2+}$ had a better antimicrobial activity and antitumor activity than the corresponding ligands due to the lipophilic nature of the metal ions in complexes, which might provide valuable information for further designing and synthesizing new antimicrobial and antitumor agents.

\section{Data Availability}

The data used to support the findings of this study are available from the corresponding author upon request.

\section{Conflicts of Interest}

The authors declare that there are no conflicts of interest regarding the publication of this paper.

\section{Authors' Contributions}

Xun-Zhong Zou and An-Sheng Feng equally contributed to this work.

\section{Acknowledgments}

This research was supported by Guangdong Province Higher Vocational Colleges \& Schools Pearl River Scholar Funded Scheme $(2015,2018)$, Guangzhou Science and Technology Program (201904010381), Pearl River Scholar Foundation of Guangdong Industry Polytechnic (RC2015-001), Scientific and Technological Innovation Project of College Students in Guangdong Province (pdjh2019b0690), Youth Innovation Talent Project of Guangdong Province (2018GkQNCX033), and Characteristic Innovation Project of Guangdong Province (2017GKTSCX005).

\section{Supplementary Materials}

Supplementary data include MOL files and InChiKeys of the most important compounds described in this article. CCDC: 2005334, L2; 1997625, 1; 2005335, 2 contain supplementary crystallographic data for $\mathbf{L} 2$ and complexes 1-2, respectively. These data can be obtained free of charge via or the Cambridge Crystallographic Data Centre, 12 Union Road, Cambridge CB2 1EZ, UK; fax: (+44) 1223-336-033; or e-mail through deposit@ccdc.cam.ac.uk. (Supplementary Materials)

\section{References}

[1] M. Suryawanshi, Patil, A. Bholay, and V. Bobade, "Metal free synthesis, docking studies and antimicrobial screening of novel isomeric pyridine substituted thiazole derivatives," Indian Journal of Chemistry - Section B Organic and Medicinal Chemistry, vol. 57, pp. 1179-1188, 2018.

[2] R. M. Mohareb, E. M. Khalil, A. E. Mayhoub, and A. E. M. Abdallah, "Novel synthesis of pyran, thiophene, and pyridine derivatives incorporating thiazole ring and their antitumor evaluation," Journal of Heterocyclic Chemistry, vol. 57 , no. 3, pp. 1330-1343, 2020.

[3] R. S. Gouhar, E. F. Ewies, M. F. El-Shehry, E. M. El-Mahdy, and M. N. F. Shaheen, "Synthesis and utility of naphthalenbenzofuran chalcone in the synthesis of new pyrazole, isooxazole, thiazole, pyrimidine, pyran, pyridine and different azide derivatives with antiviral and antitumor activity," Pharmaceutical Chemistry, vol. 10, pp. 42-54, 2018.

[4] K. Pluta, B. Morak-Młodawska, and M. Jeleń, "Recent progress in biological activities of synthesized phenothiazines," European Journal of Medicinal Chemistry, vol. 46, no. 8, pp. 3179-3189, 2011.

[5] S. Firake and S. Bari, "An insight into synthetic and docking approaches of benzenesulfonamide scaffold revealing COX-2 inhibitors," Current Enzyme Inhibition, vol. 11, no. 2, pp. 76-107, 2015.

[6] B. A. Salah, A. T. Kandil, and M. G. Abd-El-Nasser, "A review exploring the coordination chemistry of active methylene groups hydrazones," Research \& Reviews, Journal of Chemistry, vol. 8, pp. 1-8, 2019.

[7] G. Mahmoudi, E. Zangrando, A. Frontera, A. V. Gurbanov, and D. A. Safin, "New metal chelate constructed from 
$\mathrm{Ni}(\mathrm{NCS}) 2$ and 1,2-diphenyl-1,2-bis((phenyl(pyridin-2-yl) methylene)hydrazono)ethane," Inorganica Chimica Acta, vol. 509, pp. 119707-119713, 2020.

[8] M. O. Karatas, "Cycloheptyl substituted N-heterocyclic carbene PEPPSI-type palladium complexes with different $\mathrm{N}$-coordinated ligands: involvement in Suzuki-Miyaura reaction," Journal of Organometallic Chemistry, vol. 899, pp. 120906-120911, 2019.

[9] M. J. Stout, B. W. Skelton, A. N. Sobolev, P. Raiteri, M. Massi, and P. V. Simpson, "Synthesis and photochemical properties of $\operatorname{Re}(\mathrm{I})$ tricarbonyl complexes bound to thione and thiazole2-ylidene ligands," Organometallics, vol. 39, no. 17, pp. 3202-3211, 2020.

[10] T. Villaseñor-Granados, E. Díaz-Cervantes, K. J. SotoArredondo, M. Martínez-Alfaro, J. Robles, and M. A. García-Revilla, "Binding of Pb-Melatonin and $\mathrm{Pb}$ (Melatonin-metabolites) complexes with DMT1 and ZIP8: implications for lead detoxification," DARU Journal of Pharmaceutical Sciences, vol. 27, no. 1, pp. 137-148, 2019.

[11] A. I. Matesanz, J. M. Herrero, E. J. Faraco, L. Cubo, and A. G. Quiroga, "New platinum(II) triazole thiosemicarbazone complexes: analysis of their reactivity and potential antitumoral action," ChemBioChem, vol. 21, no. 8, pp. 1226-1232, 2020.

[12] G. Raymoni and A. H. Abu, "Synthesis, structures and various biological applications of new $\mathrm{Zn}$ (II) complexes having different coordination modes controlled by the drug furosemide in presence of bioactive nitrogen based ligands," Applied Organometallic Chemistry, vol. 33, no. 1, Article ID e4860, 2018.

[13] N. R. Filipovic, H. Elshaflu, S. Grubisic et al., "Co(III) complexes of (1,3-selenazol-2-yl)hydrazones and their sulphur analogues," Dalton Transactions, vol. 46, pp. 2910-2924, 2017.

[14] L. Fuks, E. Gniazdowska, P. Kozminski, and J. Mieczkowski, "Technetium(I) tricarbonyl complexed with the N-heterocyclic aldehyde thiosemicarbazones: potential precursors of the radiopharmaceuticals," Journal of Radioanalytical and Nuclear Chemistry, vol. 292, no. 1, pp. 255-259, 2012.

[15] S. Turcotte, D. A. Chan, P. D. Sutphin et al., "Preparation of pyridinyl-substituted 1,3-thiazol-2-amine derivatives useful for the treatment of cancer," PCT International Application, vol. A1, 2009.

[16] O. V. Dolomanov, L. J. Bourhis, R. J. Gildea, J. A. K. Howard, and H. Puschmann, "OLEX2: a complete structure solution, refinement and analysis program," Journal of Applied Crystallography, vol. 42, no. 2, pp. 339-341, 2009.

[17] G. M. Sheldrick, SHELXL-97, A Program for Crystal Structure Refinement, University of Göttingen, Göttingen, Germany, 1997.

[18] G. M. Sheldrick, "A short history of SHELX," Acta Crystallographica Section A. Crystal Physics, Diffraction, Theoretical and General Crystallography, vol. 64, pp. 112-122, 2008.

[19] K. Brandenburg, Program Diamond, Version 2.1c, Crystal Impact GbR, Bonn, Germany, 1999.

[20] Z. X. Zhou, Q. H. Huang, S. Zhu, and L. Zhou, "Establishment of rapid determining method for antibacterial activity by microplate reader," Weishengwu Qianyan, vol. 3, pp. 29-35, 2014.

[21] V. R. R. Malapaka, A. A. Barrese, B. C. Tripp, and B. C. Tripp, "High-throughput screening for antimicrobial compounds using a 96-well format bacterial motility absorbance assay," Journal of Biomolecular Screening, vol. 12, no. 6, pp. 849-854, 2007.
[22] M. Kimura, M.-S. Nam, Y. Ohkouchi, H. Kumura, K.-i. Shimazaki, and D.-Y. Yu, "Antimicrobial peptide of Korean native goat lactoferrin and identification of the part essential for this activity," Biochemical and Biophysical Research Communications, vol. 268, no. 2, pp. 333-336, 2000.

[23] W. J. Jiang, T. Z. Mo, F. X. Zhang, D. Z. Kuang, and T. Y. X. Syntheses, "Crystal structures and in vitro anticancer activities of dibenzyltin compounds based on the N-(2Phenylacetic acid)-aroyl hydrazone," Chinese Journal of Structural Chemistry, vol. 39, pp. 673-681, 2020.

[24] B. K. Slowikowski, H. Drzewiecka, M. Malesza, I. Madry, K. Sterzynska, and P. P. Jagodzinski, "The influence of conjugated linoleic acid on the expression of peroxisome proliferator-activated receptor- $\gamma$ and selected apoptotic genes in non-small cell lung cancer," Molecular and Cellular Biochemistry, vol. 466, no. 1-2, pp. 65-82, 2020.

[25] C. Hill, F. Bosold, K. Harms et al., "Carbene structure of stable Acyl (formyl) anion equivalents," Chemische Berichte, vol. 130, no. 9, pp. 1201-1212, 1997.

[26] I. P. Ejidike and P. A. Ajibade, "Synthesis, characterization, antioxidant, and antibacterial studies of some metal(II) complexes of tetradentate Schiff base ligand: (4e)-4-[(2-\{(E)-[1- $(2,4-$ Dihydroxyphenyl)ethylidene]amino\}ethyl)imino]pentan-2-one," Bioinorganic Chemistry and Applications, vol. 2015, Article ID 890734, 10 pages, 2015.

[27] B. G. Tweedy, "Plant extracts with metal ions as potential antimicrobial agents," Phytopathology, vol. 55, pp. 910-914, 1964.

[28] A. S. El-Tabl, M. Mohamed Abd El-Waheed, M. A. Wahba, and N. Abd El-Halim Abou El-Fadl, "Synthesis, characterization, and anticancer activity of new metal complexes derived from 2-Hydroxy-3-(hydroxyimino)-4-oxopentan2-ylidene) benzohydrazide," Bioinorganic Chemistry and Applications, vol. 2015, Article ID 126023, 14 pages, 2015. 